\title{
THE ABILITY TO EXPLORE TEXT DRAMA IN ENGLISH WITH THE CIRC (COOPERATIVE, INTEGRATED, READING AND COMPOSITION)
}

\author{
Mona Fitri Gurusinga, Meta Rosaulina, Saiful Batubara, \\ Afrilius Simanjuntak \\ Deli Husada Health Institute, Medan , Indonesia \\ E-mail: monafitrigurusinga@gmail.com
}

Received: 2021-11-09

Accepted: $2021-12-08$

\begin{abstract}
This study aims to determine the effects of the use of the Cooperative Integrated Reading and Composition (CIRC) Model on the Students' Ability to analyze the content and language of drama reading at SMA Bina Guna Tanah Jawa Balimbing, Kec. Tanah Jawa, Simalungun Regency in 2020/2021. This research was conducted based on 5 classes with a total population of class, of 160 students. From the population, a sample of 32 students was assigned to one class, selected by cluster sampling, namely class XI IPA 1. The data collection technique was used to measure students' learning outcomes in the form of assignment questions carried out on the pretest and posttest. The data analysis technique used is normality test using $\mathrm{F}$ test, homogeneity test and hypothesis testing using $t$ test. The hypothesis in this study was tested by t-test at a significant level $=0.05$. From the calculation of the data it was seen that $t$-count $>t$-table $(10.372>2000)$. Thus the null hypothesis is that $\mathrm{Ho}$ is rejected and $\mathrm{Ha}$ is accepted. From the results, it can be concluded that the Cooperative Integrated Reading and Composition (CIRC) Model can improve students learning outcomes in analyzing the content and language of drama.
\end{abstract}

Keywords: CIRC, Model, Cooperative, Integrated, Reading, Composition

\section{Introduction}

One of the literary works taught at the high school level (SMA) is a drama text. Drama is one of the literary works that describes human life based on the deeds or actions that are performed and is imaginative in the form of a script. By seeing drama, the audience or readers can see and feel the life and events seen in society.

According to Kosasih (2017: 245), there are several types of drama, namely (a) tragedy, (b) comedy, (c) melodrama, and (d) farce.

The difficulties experienced by students are that students are less able to know drama texts, less able to learn drama texts that are read, and less active and creative in learning. Referring to these problems, the solution to the causes of students' difficulties in learning drama texts in English is the use of the Cooperative Integrated Reading and Composition (CIRC) model.

The Cooperative Integrated Reading and Composition (CIRC) model is a group-based learning model that works together, and can improve students' activity and creativity. According to Istarani (2012: 112) Cooperative Integrated Learning, Reading and Composition (CIRC) is one type of cooperative learning model using small groups with heterogeneous 
The Ability to Explore Text Drama in English with The Circ (Cooperative, Integrated, Reading And Composition), Mona Fitri Gurusinga, Meta Rosaulina, Saiful Batubara, Afrilius Simanjuntak

number of members in each group of 4-5 students. The teacher starts the activity by giving clippings to the students. Next, the teacher gives a discourse/clipping according to the learning topic, and then students work together to read the text, find the main idea, provide responses to the discourse/clipping, write it down on a piece of paper, present or read the results of the group's work, and end with a joint conclusion of the teacher and the students. This is also in line with Kurniasih and Sani (2015: 89-90) who also use the model of sharing reading material to be discussed with students, namely the drama text to be analyzed. Based on the description, it can be seen that the Cooperative Integrated Reading and Composition (CIRC) is an influential model that helps students think creatively and fosters students' motivation as well as a sense of mutual respect.

According to Shoimin (2018: 51) the CIRC model is a special learning model for subjects in language in order to read and find the main idea, or theme of a discourse. CIRC learning was developed by Stevans, Madden, Slavin, and Farnish. CIRC type cooperative learning in terms of language can be interpreted as a cooperative learning model that integrates a whole reading and then composes it into important parts.

The application of the Cooperative Integrated Reading and Composition (CIRC) model in the classroom will have an impact on the formation of enthusiasm and produce friendly and creative people in solving a problem. Based on the above considerations, the researchers are interested in researching a problem with the title "The Ability to Study Dramatic Texts in English with the Model CIRC (Cooperative Integrated Reading and Composition).

\section{Literature Review}

Pattern of Application of the Cooperative Integrated, Reading and Composition (CIRC) Model is divided into several phases. The first phase is orientation. In this phase the teacher makes students' perceptions and initial knowledge of the material to be given. The teacher divides students into several groups, distributing reading material to be discussed by introducing a new concept that refers to the findings during exploration. Students communicate their findings either in groups or in front of the class. The fifth phase is the strengthening and reflection phase. In this phase the teacher provides reinforcement related to the material studied through explanation or giving real examples in everyday life. Furthermore, students are given the opportunity to reflect on and evaluate the learning outcomes.

Analyzing the content of a drama text is an investigation of the essence or something that is found in a drama text. In learning to analyze the content of drama, students are required to understand the intrinsic elements of drama.

Many verbs express what the character thinks or feels. Adjectives (descriptive language) are used to describe the characters, places or situations, such neat, clean, good, dashing, strong. The intrinsic elements are the elements of building a drama such as characters, plot, setting, dialogue, language style, themes and messages. Other important elements to be considered in a drama text are presented below.

\subsection{Language style}

According to Hasanuddin (2015: 118) language style is concerned with the author's proficiency in using language as a medium of drama. The use of language must be relevant and support the problems to be raised, in harmony with the techniques used, and be precise in formulating the plot, characterization, setting and space, and of course it boils down to 
the accuracy of the formulation of the theme or premise of the drama text. Language style is about the author's skill in using language.

\subsection{Themes and Message}

According to Hasanuddin (2015: 123), the theme is the core of the problem that the author wants to put forward in his work. Therefore, the theme is the result of the conclusion of various events related to the characterizations and setting The theme is the core problem that the author intends to raise in his work. Meanwhile, the message is the one that the writer sends to the readers, explicitly or implicitly.

3. Cognitive Development

Cognitive development is an ability related to the mastery of science if needed, the knowledge that is owned. Knowledge is a measure of a person's level of cognitive ability. There is a significant and positive relationship between intelligence and cognitive abilities.

\section{Research Method}

According to Sugiyono (2017:2), "The research method is a scientific way to obtain data with certain goals and uses". The method plays an important role in research so that the researcher's goals can be achieved optimally.

The location of the research was conducted at SMA Bina Guna Tanah Jawa Balimbing, Kec. Tanah Jawa, Kab. Simalungun Teaching Year 2020/2021.

\subsection{Population and Sample.}

According to Sugiyono (2017: 80), population is a generalization area consisting of objects/subjects that have certain qualities and characteristics determined by researchers to be studied for some conclusions.

The research population used here was all students of SMA Bina Guna Tanah Jawa Balimbing, Kec. Tanah Jawa, Kab. Simalungun of Year 2020/2021 with the following details:

1. Class XI IPA 1 of 32 students

2. Class XI IPA 2 of 32 students

3. Class XI IPA 3 of 32 students

4. Class XI IPS 1 of 32 students

5. Class XI IPS 2 of 32 students

The total number of research population is 160 students.

Sampling used in this study is a cluster-side technique because the number of participants in each class is the same and the procedures are as follows:

1. Papers containing the class names (XI IPA 1, XI IPA 2, XI IPA 3, XI IPS 1, XI IPS 2) are rolled up and put into the box.

2. Then, the paper rolls are selected based on the needs.

3 . Then the class was selected and normality test is conducted to determine whether the populations are normally distributed or not (Sudjana, 2005: 466).

\subsection{Method of Collecting Data}

The steps used in data collection are done by:

1. Giving students assignments.

2. Providing scores on student assignments.

3. Stabulating the students' pre-test and post-test scores. 
The Ability to Explore Text Drama in English with The Circ (Cooperative, Integrated, Reading And Composition), Mona Fitri Gurusinga, Meta Rosaulina, Saiful Batubara, Afrilius Simanjuntak

4. Calculating the average score for the sampling data, namely the pre-test and posttest data.

Role and Duties of Researchers.

Researcher 1

1. Establishing a theoretical framework

2. Determining the criteria for respondents

3. Making the data collection

4. Making the data analysis

5. Presenting the research results

6. Preparing the article publication

\section{Researcher 2}

1. Assisting researcher 1 in conducting a research design

2. Helping researcher 1 one in carrying out research implementation

3. Assisting researcher 11 in collecting data

4. Assisting researcher 1 in conducting data analysis, data editing and data processing

5. Making a research report

\subsection{Composition (CIRC) Model}

The pattern of implementing the CIRC learning model is divided into several phases. The first phase is orientation. In this phase the teacher makes students' perceptions and initial knowledge of the material to be given. The second phase is organization. The teacher divides students into several groups, divides reading material about the material to be discussed with students. The third phase is the concept of introduction, that is introducing a new concept that refers to the findings during the exploration. The fourth phase is the publication phase. Students communicate their findings and demonstrate the materials discussed, either in groups and in front of the class. The fifth phase is the strengthening and reflection phase. In this phase the teacher provides reinforcement related to the materials studied through explanation or giving real examples in everyday life. Furthermore, students are given the opportunity to reflect on and evaluate the learning outcomes.

\begin{tabular}{|l|l|l|l|}
\hline No. & Characteristics of Respondents & \multicolumn{2}{|c|}{ Total } \\
\cline { 3 - 4 } & & & \multicolumn{2}{|c|}{ f } \\
\hline 1 & Gender & 13 & 40,7 \\
& $-\quad$ Man & 19 & 59,3 \\
\hline \multirow{2}{*}{2} & Total & $\mathbf{3 2}$ & 100 \\
& Pretest score assessment (X) & & \\
& Total Score & 1900 & \\
& Average (mean) & 59,38 & \\
& Standard deviation of variable X & 7,27 & \\
& variable standard error X & 1,31 & \\
& Variant X & 52,8529 \\
& The highest score & 80 & \\
& Lowest score & 52 & \\
& Range (highest-lowest score) & 28 & \\
\hline
\end{tabular}

Table 3.1. Students' Pretest Results (X) in Analyzing the Content and Text Drama 


\begin{tabular}{|l|l|l|l|}
\hline \multirow{2}{*}{ No. } & Characteristics of Respondents & \multicolumn{2}{|c|}{ Total } \\
\cline { 3 - 4 } & & \multicolumn{2}{|c|}{ f } \\
\hline 1. & post-test score assessment $(Y)$ & \multicolumn{3}{|}{} \\
& Total Score & 2534 & \\
& Average (mean) & 79,19 \\
Standard deviation of variable $Y$ & 7,97 \\
& variable standard error $Y$ & 1,43 & \\
Variant $Y$ & 63,5209 \\
The highest score & 94 & \\
Lowest score & 60 \\
& Range (highest-lowest score) & 34 \\
\hline
\end{tabular}

Table 3.2. Posttest Results (Y) of Students in Analyzing Text Drama

\begin{tabular}{|l|l|l|l|}
\hline \multirow{2}{*}{ No. } & \multicolumn{2}{|c|}{ Category } & \multicolumn{2}{c|}{ fotal } \\
\cline { 3 - 4 } & & \multicolumn{1}{c|}{ f } & \multicolumn{1}{c|}{$\%$} \\
\hline 1 & Not Very Good (51-55) & 12 & 37,5 \\
\hline 2 & Not Good (56-60) & 10 & 31,25 \\
\hline 3 & Pretty Good (61-65) & 5 & 15,625 \\
\hline 4. & Pretty Good (66-70) & 2 & 6,25 \\
\hline 5 & Good (71-75) & 1 & 3,125 \\
\hline 6 & Good (76-80) & 2 & 6,25 \\
\hline \multicolumn{2}{|l|}{ Total } & 32 & $\mathbf{1 0 0}$ \\
\hline
\end{tabular}

Table 3.3. Table Identification of Pretest Data Trends (X)

\begin{tabular}{|l|l|l|l|}
\hline \multirow{2}{*}{ No. } & \multicolumn{1}{|c|}{ Category } & \multicolumn{2}{|c|}{ Total } \\
\cline { 3 - 4 } & & \multicolumn{1}{|c|}{ f } & \multicolumn{1}{c|}{$\%$} \\
\hline 1 & Not Good (59-64) & 1 & 3,125 \\
\hline 2 & Pretty Good (65-70) & 5 & 15,625 \\
\hline 3 & Good (71-76) & 6 & 18,75 \\
\hline 4 & Good (77-82) & 12 & 37,5 \\
\hline 5 & Very Good (83-88) & 4 & 12,5 \\
\hline 6 & Very Good (89-94) & 4 & 12,5 \\
\hline & Total & $\mathbf{3 2}$ & $\mathbf{1 0 0}$ \\
\hline
\end{tabular}

Table 3.4. Trend identification Table Post-test data (Y)

\begin{tabular}{|l|l|l|l|}
\hline Data & $\mathbf{L}_{\text {count }}$ & $\mathbf{L}_{\text {table } \quad(\boldsymbol{\alpha}=\mathbf{0 , 0 5})}$ & Conclusion \\
\hline Pretest $(\mathrm{X})$ & 0,1516 & 0,1566 & Normal \\
\hline Post-test $(\mathrm{Y})$ & 0,1132 & 0,1566 & Normal \\
\hline
\end{tabular}

Table 3.5. Table of Normality Test of Pretest and Post-test Research Data

\begin{tabular}{|l|l|l|l|l|}
\hline Data & Total & $\mathbf{F}_{\text {count }}$ & $\mathbf{F}_{\text {tabele }}$ & \multicolumn{1}{c|}{ Conclusion } \\
\hline Variant $\mathbf{Y}$ & 63,8529 & 1,21 & 1,84 & $\begin{array}{l}\text { Pre-test and post-test } \\
\text { Homogeneus }\end{array}$ \\
\hline Variant X & $\mathbf{5 2 , 8 5 2 9}$ & & & \\
\hline
\end{tabular}


The Ability to Explore Text Drama in English with The Circ (Cooperative, Integrated, Reading And Composition), Mona Fitri Gurusinga, Meta Rosaulina, Saiful Batubara, Afrilius Simanjuntak

Table 3.6. Homogeneity Test Table

\begin{tabular}{|l|l|l|l|l|l|}
\hline Data & Everage & $\begin{array}{l}\text { Variance } \\
\text { Combain }\end{array}$ & T count & T tabel & Conclusion \\
\hline Pre-test $(\mathrm{X})$ & 59,38 & 7,64 & 10,372 & 2,000 & $\begin{array}{l}\text { There is a } \\
\text { significant } \\
\text { influence }\end{array}$ \\
\hline Post-test $(\mathrm{Y})$ & 79,19 & & & & \\
\hline
\end{tabular}

Table 3.6. Research Hypothesis Testing Table

\section{Results and Discussion}

Based on the results of research conducted by the researchers, the students' pretest scores showed that the average score of students in analyzing the content and language of dramas read before using the Cooperative Integrated Reading and Composition (CIRC) model was 59.38, categorized as poor with a standard deviation (SD) of 7, 27 where the highest score obtained by students is 80 and the lowest score is 52 .

For the students' posttest scores, it was found that the average score of students in analyzing the content and language of the drama that was read after using the model. Cooperative Integrated Reading and Composition (CIRC) is 79.19 in good category with a standard deviation (SD) of 7.97 where the highest score of students is 94 and the lowest score of students is 60 .

Based on the data analysis using the $t$ test, it was obtained that $t$ was 10.372 when compared with the $t$ price at a significant level of 0.05 of 2,000 indicating $t>t(10.372>$ $2,000)$. Based on the t-test data, it shows that $\mathrm{Ha}$ is accepted and Ho is rejected, so the Cooperative Integrated Reading and Composition (CIRC) model can improve students' ability to analyze the content and language of the drama that is read. The proof of the data can be seen from the description of the data and data analysis.

The use of the Cooperative Integrated Reading and Composition (CIRC) model has a significant effect on the ability of students to analyze the content and language of drama in class XI SMA Bina Guna Tanah Jawa. It can be seen from the analysis of research data that $t-$ count $>$ t-table $(10.372>2,000)$ so it can be stated that $\mathrm{Ha}$ is accepted and $\mathrm{HO}$ is rejected.

Based on research before using the Cooperative Integrated Reading and Composition (CIRC) model in the pretest test, there are still many students who have not been able to analyze the content and language of the drama that is read. Judging from the data from the pretest assessment, it was found that the number of students in the category of very unfavorable was 12 students, the score in the poor category was 10 students, the score in the category of good enough was 7 students, and the score in the good category was 3 students. The highest score obtained by students is 80 and the lowest score is 52 students with an average pretest score of 59.38 with a standard deviation (SD) of 7.27.

Based on the research, after using the Cooperative Integrated Reading and Composition (CIRC) model on the posttest test, students were able to analyze the content and language of drama well. Judging from the data of the posttest assessment results, the total number of students getting bad category was 1 , the score categorized as good enough amounting to 5 students, the score categorized as good amounting to 18 students, the score categorized as very good amounting to 8 students, the highest score the students obtained was 94 and the lowest score was 60, students with an average pretest score of 79.19 with a standard deviation (SD) of 7.97 . 


\section{Conclusion}

Based on the research conducted by the researchers on the application of the Cooperative Integrated Reading and Composition (CIRC) model to improve the ability to analyze the content and language of drama read by students, it can be concluded that:

a. The ability of students of Bina Guna Tanah Jawa Private High School to analyze the content and linguistics aspects of drama before using the Cooperative Integrated Reading and Composition (CIRC) model showed that the average score of 59.38 students was categorized poor with a standard deviation (SD) of 7.27, meanwhile the highest score is 80 and the lowest score is $\mathbf{5 2}$.

b. The ability of students of Bina Guna Tanah Jawa to analyze the content and linguistics aspects of the drama texts after using the Cooperative Integrated Reading and Composition (CIRC) model showed that the students' average score was 79.19 in good category with a standard deviation (SD) of 7.97, meanwhile the highest score is 94 and the lowest is 60 .

c. Based on the results of the analysis conducted with $t=10.372$ when compared with the score of $t$ at a significant level of 0.05 of 2,000, it shows $t>t(10.372>2,000)$. Then the alternative hypothesis $(\mathrm{Ha})$ is accepted and the null hypothesis $(\mathrm{Ho})$ is rejected, this proves that the use of the Cooprative Integrated Reading and Composition (CIRC) model has an effect on the ability to analyze the content and linguistic aspects of the drama read by the students of SMA Bina Guna Tanah Jawa.

\section{References}

Hasanuddin. (2015). Drama Works in Two Dimensions. Bandung: Space

Istarani. (2012). Innovative Learning Models. Medan: Media Persada.

Kosasih. (2013). Types of Text. Bandung: Yrama Widya.

Kurniasih, I., \& Berlin, S. (2015). Variety of Learning Model Development. Yogyakarta: Pena said.

Shoimin, A. (2018). Innovative Learning Models in the 2013 Curriculum. Yogyakarta: Ar-Ruzz Media.

Sudjana. (2005). Statistical Methods. Bandung: Tarsito

Sugiyono. (2017). Quantitative, Qualitative and R\&D Research Methods. Bandung: Alphabeta. 